\title{
Effects of unaltered and bioconverted mulberry leaf extracts on cellular glucose uptake and antidiabetic action in animals
}

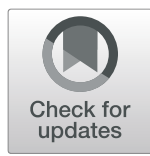

Sang-Hyuk Jung ${ }^{1}$, Joo-Hui Han', Hyun-Soo Park', Do-Hyung Lee', Seok Jin Kim², Hyun So Cho², Jong Seong Kang ${ }^{1}$ and Chang-Seon Myung ${ }^{1 *}$ (D)

\begin{abstract}
Background: Mulberry is a Korean medicinal herb that shows effective prevention and treatment of obesity and diabetes. Bioconversion is the process of producing active ingredients from natural products using microorganisms or enzymes.

Methods: In this study, we prepared bioconverted mulberry leaf extract (BMLE) with Viscozyme L, which we tested in insulin-sensitive cells (i.e., skeletal muscle cells and adipocytes) and insulin-secreting pancreatic $\beta$-cells, as well as obese diabetic mice induced by co-administration of streptozotocin ( $100 \mathrm{mg} / \mathrm{kg}$, IP) and nicotinamide ( $240 \mathrm{mg} / \mathrm{kg}$, IP) and feeding high-fat diet, as compared to unaltered mulberry leaf extract (MLE).

Results: BMLE increased the glucose uptake in C2C12 myotubes and 3 T3-L1 adipocytes and increased glucosestimulated insulin secretion in HIT-T15 pancreatic $\beta$-cells. The fasting blood glucose levels in diabetic mice treated with BMLE or MLE (300 and $600 \mathrm{mg} / \mathrm{kg}, \mathrm{PO}, 7$ weeks) were significantly lower than those of the vehicle-treated group. At the same concentration, BMLE-treated mice showed better glucose tolerance than MLE-treated mice. Moreover, the blood concentration of glycated hemoglobin $\left(\mathrm{HbA}_{1} \mathrm{c}\right)$ in mice treated with BMLE was lower than that in the MLE group at the same concentration. Plasma insulin levels in mice treated with BMLE or MLE tended to increase compared to the vehicletreated group. Treatment with BMLE yielded significant improvements in insulin resistance and insulin sensitivity.

Conclusion: These results indicate that in the management of diabetic condition, BMLE is superior to unaltered MLE due to at least, in part, high concentrations of maker compounds (trans-caffeic acid and syringaldehyde) in BMLE.
\end{abstract}

Keywords: Bioconversion, Insulin resistance, Insulin sensitivity, Mulberry leaf extract, Diabetic animals

\section{Background}

Mulberry has origins in Korea, China, and Japan, and was traditionally cultivated for medicinal materials and silkworm food from all plant parts (e.g., leaves, fruit, and root bark) [1, 2]. In China and Korea, it has long been used as a treatment for obesity and diabetes. Recent studies have reported several pharmacological effects of mulberry leaves, including blood pressure stabilization [3], cholesterol reduction [4], thrombolysis [5], antioxidation [6], and antiobesity [7-9]. In particular, a number of human $[10,11]$ or animals $[12-16]$ studies have reported to

\footnotetext{
* Correspondence: cm8r@cnu.ac.kr

'Department of Pharmacology, Chungnam National University College of Pharmacy, 99 Daehak-ro (St.), Yuseong-gu, Daejeon 34134, Republic of Korea Full list of author information is available at the end of the article
}

confirm the antidiabetic activity of mulberry extract by regulating blood glucose level.

Bioconversion is a technique used to induce the production of physiologically active ingredients by changing the structure of chemicals in natural products using biological methods such as microbial fermentation and enzyme treatment $[17,18]$. Several studies have reported that bioconversion can improve the biological activity of extracts. For example, bioconverted Citrus unshiu peel extract with cytolase showed the ability to inhibit lipogenesis in 3 T3-L1 cells [19], and fermented soybean alleviated type 2 diabetes [20]. Moreover, bioconverted Morinda citrifolia (Noni) using cheonggukjang improved the management of type 2 diabetes [21], and fermented red ginseng by Lactobacillus plantarum showed the

(c) The Author(s). 2019 Open Access This article is distributed under the terms of the Creative Commons Attribution 4.0 International License (http://creativecommons.org/licenses/by/4.0/), which permits unrestricted use, distribution, and reproduction in any medium, provided you give appropriate credit to the original author(s) and the source, provide a link to the Creative Commons license, and indicate if changes were made. The Creative Commons Public Domain Dedication waiver (http://creativecommons.org/publicdomain/zero/1.0/) applies to the data made available in this article, unless otherwise stated. 
ability to regulate postprandial blood glucose levels in type 2 diabetic patients [22]. Similarly, chickpea (Cicer arietinum L.) bioconverted by Rhizopus oligosporus showed improvements in blood glucose levels [23]. It has been reported that Viscozyme L, a carbohydrate-hydrolyzing enzyme from Aspergillus aculeatus with 100 fungal $\beta$-glucanase units, was used for bioconverstion of unripe apples and this had the strongest effect on polyphenols extraction to yield components [24]. Thus, this enzyme may be a good tool for bioconversion of natural products.

Type 2 diabetes can be induced in animal models by co-administration of streptozotocin (STZ) and nicotinamide (NA) [25-29]. Although STZ destroys pancreatic $\beta$-cells and NA can partially protect $\beta$-cells, levels of N1-methylnicotinamide, a metabolite of NA, increase in the plasma when excess NA is administered, leading to oxidative stress, insulin resistance, and ultimately type 2 diabetes [30]. In type 2 diabetic animal models, glucose and glycated hemoglobin $\left(\mathrm{HbA}_{1 \mathrm{C}}\right)$ blood levels and the ability of pancreatic $\beta$-cells to secret insulin are important indices for the evaluation of diabetes [31,32].

In this study, we prepared bioconverted mulberry leaf extract (BMLE) using Viscozyme L, a multi-enzyme complex with a strong pectolytic activity and a wide range of carbohydrases including arabanase, cellulase, $\beta$-glucanase, hemicellulase, and xylanase (Manufacturer's Application sheet). The ability of BMLE to uptake glucose into insulin-sensitive cells ( $\mathrm{C} 2 \mathrm{C} 12$ myotubes and 3 T3-L1 adipocytes) and secret insulin from HIT-T15 pancreatic $\beta$-cells, as well as to lower blood glucose and $\mathrm{HbA}_{1 \mathrm{C}}$ levels and secret insulin in obese diabetic mice induced by co-administration of STZ and NA and feeding high-fat diet, as compared to unaltered mulberry leaf extract (MLE).

\section{Methods}

\section{Reagents}

Dulbecco's Modified Eagle Medium (DMEM), fetal bovine serum (FBS), RPMI-1640 medium, phosphate-buffered saline (PBS), and trypsin-EDTA were obtained from Gibco BRL (Grand Island, NE, USA). Penicillin/streptomycin was obtained from Thermo Fisher Scientific (Rockford, IL, USA). Insulin, NA, STZ, glimepiride, metformin, D-(+)-glucose, 2-deoxy-D-glucose, 3-isobutyl-1-methylxanthine (IBMX), 4-(2-hydroxyethyl)-1-piperazineethanesulfonic acid (HEPES), $\mathrm{NaCl}, \mathrm{KCl}, \quad \mathrm{MgSO}_{4}, \mathrm{CaCl}_{2}, \mathrm{KH}_{2} \mathrm{PO}_{4}$, and $\mathrm{NaHCO}_{3}$ were obtained from Sigma-Aldrich (St. Louis, MO, USA). 3-(4,5-Dimethylthiazol-2-yl)-2,5,-diphenyltetrazolium bromide was obtained from VWR Life Science (Radnor, PA, USA). 2-Deoxy- $\left[{ }^{3} \mathrm{H}\right]$-glucose was obtained from PerkinElmer Life Sciences (Boston, MA, USA). Rosiglitazone was obtained from Masung \& Co., Ltd. (Seoul, Korea). All other chemicals were of analytical grade. Trans-Caffeic acid and syringaldehyde were purchased from Sigma-Aldrich (St. Louis, Mo, USA). Other standard compounds (morin 3-O- $\beta$-D-glucopyranoside, moracin $\mathrm{M}$ 3 '-O- $\beta$-glucopyranoside, and astragalin) were provided by Professor Young Ho Kim in College of Pharmacy at Chungnam National University (Daejeon, South Korea). All standards were higher than $95 \%$ of purity. Methanol, ethyl acetate and acetonitrile were purchased with HPLC grade from Honeywell Burdick \& Jackson (Muskegon, MI, USA). Formic acid (HPLC grade) was purchased from Sigma-Aldrich Corporation (St. Louis, MO, USA). Other chemicals used were GR (Guaranteed Reagent) grade. Ultrapure water was manufactured by a Milli-Q water purification system (ShinHan, Daejeon, South Korea). Anti-phospho-AKT serine 473 (S473) and AKT antibodies were obtained from Cell Signaling Technology, Inc. (Beverly, MA, USA). Anti- $\beta$-actin and anti-rabbit antibodies were purchased from AbFrontier (Geumcheon, Seoul, Korea).

\section{Mulberry leaf extraction}

Dried mulberry leaves were purchased in September 2015 at the Naemome Dah herb company in Ulsan, Korea. The herb was taxonomically identified by Professor Young Ho Kim who is an expert in the area of Natural Product Chemistry. A voucher specimen (CNU 16004) was deposited at the Herbarium of College of Pharmacy, Chungnam National University, Daejeon, Korea. Dried leaves (100 g) were reconstituted in about 20 times its weight of purified water, pressure-extracted at $121^{\circ} \mathrm{C}$ for $3 \mathrm{~h}$, and then filtered. The filtered extract was concentrated using a vacuum concentrator (Rovator R-200; BÜCHI Korea Inc., Seoul, Korea) and $16 \mathrm{~g}$ powder was obtained using a freeze dryer. Solutions of the resulting MLE powder were created at a concentration of 300 or $600 \mathrm{mg} / \mathrm{kg}$ in normal saline for the animal experiments.

\section{Bioconversion of MLE with Viscozyme L}

Water MLE was adjusted to $\mathrm{pH} 4.5$, the enzyme Viscozyme L (Novozyme, Copenhagen, Denmark) was added at a concentration of $1 \%$ dried leaf, and the fermentation process was conducted at $45^{\circ} \mathrm{C}$ for $15 \mathrm{~h}$, after which the enzyme activity was terminated at $90^{\circ} \mathrm{C}$ for $30 \mathrm{~min}$. The solution was filtered, concentrated using a vacuum evaporator, and freeze-dried to obtain $19 \mathrm{~g}$ powder. The resulting BMLE powder was used at concentrations of 300 or $600 \mathrm{mg} / \mathrm{kg}$ in normal saline for the animal experiments.

\section{Sample preparation and HPLC analysis}

The marker compounds in BMLE and MLE used in this study were analyzed by Prof. Jong Seong Kang in College of Pharmacy at Chungnam National University (Daejeon, South Korea). This method is under review for Analytical Journal. 


\section{Animals}

Five-week-old C57BL/6 mice (18-23 g) were purchased from OrientBio (Seongnam, Korea). The mice were acclimatized for 1 week at $22 \pm 2{ }^{\circ} \mathrm{C}$ and $40 \pm 5 \%$ humidity, and allowed free access to a normal- or high-fat diet (60\% kcal fat, Research Diets, Inc., New Brunswick, NJ, USA) and drinking water. All animal handling was performed according to the guidelines of the Committee for Ethical Usage of Experimental Animals at Chungnam National University (CNU-00773; Daejeon, South Korea). In all experiments using animals, an inhalational anesthetic, isoflurane, was used to alleviate animal pain, and they were euthanized by cervical dislocation after completing experiments.

\section{Induction of obese diabetic mice}

After fasting for $16 \mathrm{~h}$, mice fed on high-fat diet for 8 weeks were intraperitoneally (IP) injected by NA $(240 \mathrm{mg} / \mathrm{kg}) 15$ min before administration of STZ (100 mg/kg, IP) to induce obese diabetic condition as described previously [28, 29, 33]. To confirm whether a diabetic condition was established in animals, oral glucose tolerance test (OGTT) was performed and the results were compared with type 1 diabetic mice induced by administration of STZ (100 mg/kg) alone. These results showed that STZ-NA-induced diabetic mice had different conditions from STZ-induced ones (Additional file 1).

\section{Experimental design}

The experimental mice were randomly divided into eight groups containing seven mice in each group as follows:

Group 1 (ND): normal-diet-fed mice treated with normal saline

Group 2 (HFD): high-fat-diet-fed mice treated with normal saline

Group 3 (Vehicle): obese diabetic mice treated with normal saline

Group 4 (MLE-300 mg/kg): obese diabetic mice treated with $300 \mathrm{mg} / \mathrm{kg}$ MLE

Group 5 (MLE-600 mg/kg): obese diabetic mice treated with $600 \mathrm{mg} / \mathrm{kg} \mathrm{MLE}$

Group 6 (BMLE-300 mg/kg): obese diabetic mice

treated with $300 \mathrm{mg} / \mathrm{kg}$ BMLE

Group 7 (BMLE-600 mg/kg): obese diabetic mice treated with $600 \mathrm{mg} / \mathrm{kg}$ BMLE

Group 8 (Metformin-300 mg/kg): obese diabetic mice treated with $300 \mathrm{mg} / \mathrm{kg}$ metformin as a positive control. All agents or vehicles were daily oral-administered to animals in all groups for 7 weeks.

\section{Oral glucose tolerance test}

One week before the end of the experiment, all mice in the eight groups were fasted for $16 \mathrm{~h}$. Glucose $(2 \mathrm{~g} / \mathrm{kg}$, PO) was administered $30 \mathrm{~min}$ after the administration of the vehicle or agents, and blood was collected from the tail vein of each animal at $0,15,30,45,60$, and $120 \mathrm{~min}$ to measure blood glucose with a blood glucose meter (Accu-Chek; Roche Diagnostics Korea Co., Ltd., Seoul, Korea). The OGTT data were plotted using GraphPad, and significant differences among groups were evaluated by measuring the AUC of each line graph.

\section{Insulin tolerance test}

The ITT followed the same protocol as the OGTT, except for the subcutaneous administration of insulin $(1 \mathrm{U} / \mathrm{kg})$ $30 \mathrm{~min}$ after glucose administration $(2 \mathrm{~g} / \mathrm{kg}, \mathrm{PO})$. Blood was collected from the tail vein of each animal after 0,30 , 45,60 , and $120 \mathrm{~min}$, and blood glucose was measured. The data interpretation was the same as that described for the OGTT.

\section{Insulin measurement}

Mice were fasted for $16 \mathrm{~h}$ before the final administration of vehicle or agent. Mice were anesthetized $30 \mathrm{~min}$ after the final administration via isoflurane inhalation $(2-3 \%$ isoflurane with oxygen supply; Isoflurane 100, JW PHARMA, Daejeon, Korea). After laparotomy, about 0.7-1 mL blood was collected through the abdominal artery in the EDTA-coated tube. Plasma was separated by centrifugation at $4000 \mathrm{rpm}$ for $15 \mathrm{~min}$, and plasma insulin was measured with a mouse insulin ELISA kit (Cat. AKRIN-011 T; Shivayagi, Gunma, Japan) according to the manufacturer's instructions. The amount of insulin released from HIT-T15 cells into the media was measured as previously described [34]. HIT-T15 pancreatic $\beta$-cells seeded on a 24 -well at a density of $2 \times 10^{5}$ cells/ well were treated with RPMI-1640 medium supplemented with $10 \%$ FBS and $11.1 \mathrm{mM}$ glucose and were cultured for 2 days. After washing with Krebs-Ringer bicarbonate-HEPES (KRBH) buffer (119 mM NaCl, 4.74 $\mathrm{mM} \mathrm{KCl}, 2.54 \mathrm{mM} \mathrm{CaCl} 2 \cdot 2 \mathrm{H}_{2} \mathrm{O}, 1.19 \mathrm{mM} \mathrm{MgCl} 2 \cdot 6 \mathrm{H}_{2} \mathrm{O}$, $1.19 \mathrm{mM} \mathrm{KH}_{2} \mathrm{PO}_{4}, 25 \mathrm{mM} \mathrm{NaHCO}$, and $7 \mathrm{mM}$ HEPES; $\mathrm{pH}$ 7.4) without glucose, cells were incubated in $\mathrm{KRBH}$ buffer with $0.3 \%$ bovine serum albumin for $30 \mathrm{~min}$, which was exchanged with KRBH buffer containing 11.1 $\mathrm{mM}$ glucose, and then treated with the prescribed agent for $1 \mathrm{~h}$. Insulin levels released from cells into the $\mathrm{KRBH}$ buffer were measured with an insulin assay kit as described above. After lysing cells with $150 \mu \mathrm{L} 0.5 \mathrm{~N}$ $\mathrm{NaOH}$, the protein concentration in cell lysate was measured. Standard curves were established using the standard materials included in the ELISA kit, and plasma insulin levels $(\mathrm{ng} / \mathrm{mL}$ ) and insulin secretion (ng insulin/ mg protein) were measured using a microplate reader (Infinite M200 PRO; Tecan Group Ltd., Zürich, Switzerland) at $450 \mathrm{~nm}$. 


\section{$\mathrm{HbA}_{1 \mathrm{C}}$ analyses}

$\mathrm{HbA}_{1 \mathrm{C}}$ levels in the whole blood of mice were measured using a mouse $\mathrm{HbA}_{1 \mathrm{C}}$ Assay Kit (Cat. 80,310; Crystal Chem, Elk Grove Village, IL, USA) according to the manufacturer's instructions. After establishing a standard curve, $\mathrm{HbA}_{1 \mathrm{C}}$ levels were determined using a microplate reader at $700 \mathrm{~nm}$ [35].

\section{Calculation of HOMA-IR and QUICKI}

The HOMA-IR and QUICKI indices were calculated as follows:

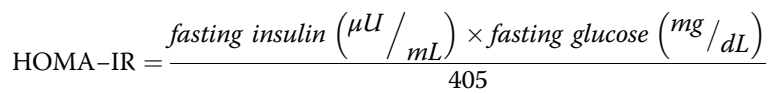

$$
\begin{aligned}
& \text { QUICKI }=\frac{1}{[\log \text { fasting insulin }(m U / L)+\log \text { fasting glucose }(m g / d L)]}
\end{aligned}
$$

\section{Cell culture and differentiation}

C2C12 myotubes and 3 T3-L1 adipocytes were cultured and differentiated as previously described [36, 37]. Briefly, C2C12 myoblasts were cultured at $37^{\circ} \mathrm{C}$ under a $5 \% \mathrm{CO}_{2}$ atmosphere in DMEM containing 10\% FBS. Confluent myoblasts were designated as day 0 , and DMEM containing 1\% FBS was replaced daily for 6 days to differentiate $\mathrm{C} 2 \mathrm{C} 12$ myotubes. $3 \mathrm{~T} 3-\mathrm{L} 1$ preadipocytes were cultured at $37^{\circ} \mathrm{C}$ in a $5 \% \mathrm{CO}_{2}$ atmosphere in DMEM containing $10 \%$ calf serum for 2 days, and confluent 3 T3-L1 cells were designated as day 0. Cells at day 0 were treated with $10 \%$ FBS, $0.5 \mathrm{mM}$ IBMX, $1 \mu \mathrm{M}$ dexamethasone, and $1 \mu \mathrm{g} / \mathrm{mL}$ insulin for 3 days to induce differentiation. After 3 days of differentiation, cells were maintained in DMEM containing $10 \%$ FBS and $1 \mu \mathrm{g} / \mathrm{mL}$ insulin for 2 days. Then the cell medium was replaced with DMEM containing 10\% FBS, which was replaced every 2 days until day 8 . HIT-T15 pancreatic $\beta$-cells were cultured at $37^{\circ} \mathrm{C}$ in a $5 \% \mathrm{CO}_{2}$ atmosphere in RPMI-1640 culture medium containing 10\% FBS, $0.8 \mathrm{mM}$ glucose, $100 \mathrm{U} / \mathrm{mL}$ penicillin, and $100 \mu \mathrm{g} / \mathrm{mL}$ streptomycin, and were subcultured for 3-5 days [34].

\section{Glucose uptake measurement}

3 T3-L1 adipocytes or C2C12 myotubes grown in DMEM with $1 \%$ FBS were treated with Krebs-Ringer phosphate-HEPES buffer $(136 \mathrm{mM} \mathrm{NaCl}, 4.7 \mathrm{mM} \mathrm{KCl}, 1$ $\mathrm{mM} \mathrm{MgSO}_{4}, 1 \mathrm{mM} \mathrm{CaCl}, 10 \mathrm{mM}$ phosphate buffer, and 10 mM HEPES; pH 7.4). Cells were treated with medium alone (basic glucose uptake) or with $100 \mathrm{nM}$ insulin (insulin-stimulated glucose uptake) for $30 \mathrm{~min}$. Glucose uptake was initiated with adding $100 \mu \mathrm{M}$ 2-deoxy-D-glucose together with 2 -deoxy- $\left[{ }^{3} \mathrm{H}\right]$-glucose $(0.1 \mu \mathrm{Ci} / \mathrm{mL}$ in $3 \mathrm{~T} 3$-L1 adipocytes or $0.5 \mu \mathrm{Ci} / \mathrm{mL}$ in $\mathrm{C} 2 \mathrm{C} 12$ myotubes) per well. After $10 \mathrm{~min}$, the cells were washed three times with cold
PBS and lysed using $0.5 \mathrm{M} \mathrm{NaOH}$ and $0.1 \%$ sodium dodecyl sulfate. The radioactivity was determined using liquid scintillation counting with a $\beta$-counter (1600TR; BioSurplus, Inc., San Diego, CA, USA) and normalized according to the total protein level [36, 37].

\section{Western blot analysis}

Total proteins in differentiated $\mathrm{C} 2 \mathrm{C} 12$ cells were extracted using RIPA buffer and quantified with BCA protein assay kit (Thermo Fisher Scientific, Rockford, IL, USA). Proteins in the sample buffer were boiled for 10 min and resolved by $10 \%$ sodium dodecyl sulfate polyacrylamide gel electrophoresis (SDS-PAGE). Proteins were transferred to a polyvinylidene fluoride (PVDF) membrane (ATTO Corp., Tokyo, Japan) at $4{ }^{\circ} \mathrm{C}$ for 80 $\mathrm{min}$ at $120 \mathrm{~mA}$. After blocking with TBS-T (10 mM Tris, $150 \mathrm{mM} \mathrm{NaCl}, 0.1 \%$ Tween-20, $\mathrm{pH} 7.6$ ) containing 5\% bovine serum albumin (BSA) for $1 \mathrm{~h}$, the membranes were then incubated with a 1:1000 dilution of primary antibodies targeting the following; phospho-AKT (S473), $\mathrm{AKT}$, and $\beta$-actin. After removing primary antibodies, the blots were washed three times in TBS-T, incubated with anti-rabbit antibody diluted 1:2000 in TBS containing $5 \% \mathrm{BSA}$ for $5 \mathrm{~h}$ at $4{ }^{\circ} \mathrm{C}$ and then washed five times in TBS-T. Antibody-bound proteins were detected using enhanced chemiluminescence (AbFrontier, Seoul, Korea) and imaging systems (Bio-Rad, Hercules, CA, USA) according to the manufacturer's instruction. The expression level of each protein was normalized to $\beta$-actin and the intensities of the bands were quantified using Quantity One (Bio-Rad, Hercules, CA, USA) [38, 39].

\section{Statistical processing}

We statistically analyzed the experimental results with Dunnett's test after performing one-way analysis of variance. All data are expressed as the means \pm standard error of the mean (SEM), and $p<0.05$ was considered statistically significant.

\section{Results}

The content of two marker compounds and their abilities to increase glucose uptak in $\mathrm{C} 2 \mathrm{C} 12$ myotubes

HPLC analysis showed two major marker compounds in MLE, compounds 1 (trans-caffeic acid, Fig. 1a) and 2 (syringaldehyde, Fig. 1b), and the quantities of these two compounds in BMLE were increased by 184 and $280 \%$, respectively (Table 1 ), indicating that bioconversion process increases the quantity of marker compounds compared with unaltered MLE. To confirm the abilities of two marker compounds to uptake glucose into cells, two compounds with variable concentrations $(0.5-5 \mu \mathrm{M})$ were applied to $\mathrm{C} 2 \mathrm{C} 12$ myotubes. Both trans-caffeic acid and syringaldehyde significantly increased insulin-stimulated glucose uptake in a concentration-dependent manner (Fig. 1c). These 


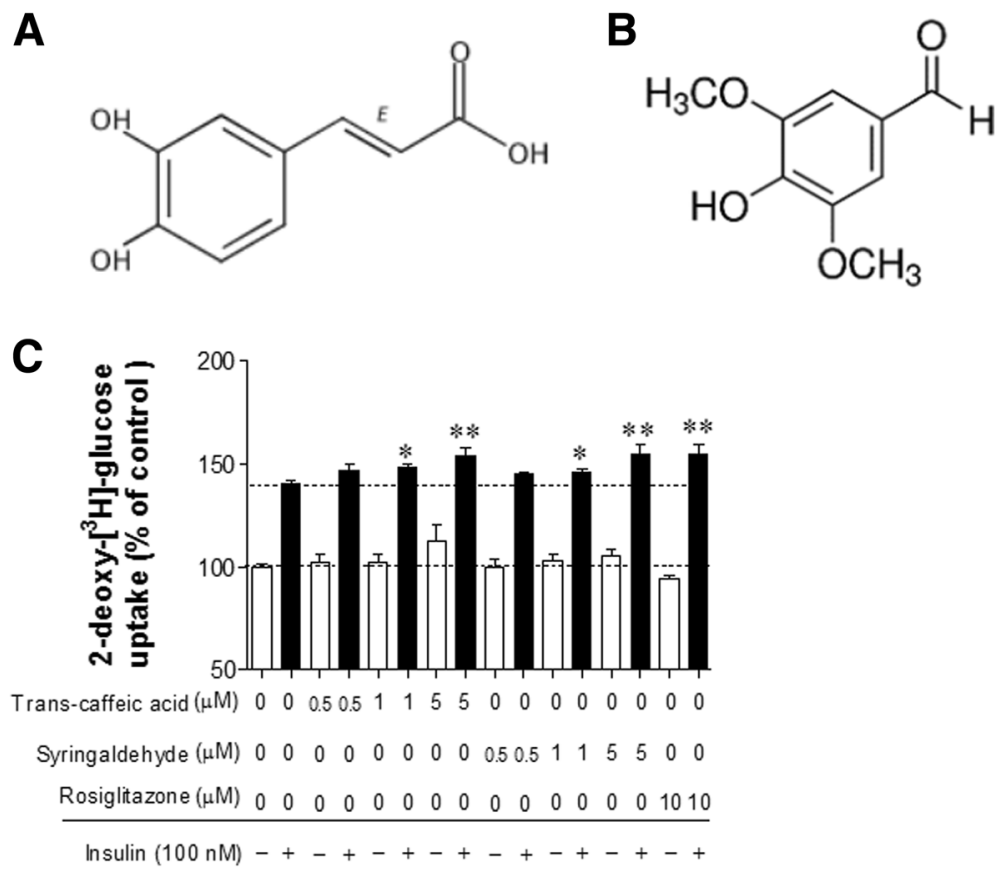

Fig. 1 Structures of two marker compounds in mulberry leaf extract and the effect of these two compounds on glucose uptake in differentiated C2C12 myotubes (c). Structures of trans-caffeic acid (a) and syringaldehyde (b). Differentiated C2C12 cells were incubated in serum-starved DMEM for $1 \mathrm{~h}$ and then treated with trans-caffeic acid or syringaldehyde $1 \mathrm{~h}$. Thereafter, the medium was changed to Krebs-Ringer phosphate-HEPES buffer containing the prescribed concentrations of trans-caffeic acid or syringaldehyde for 30 min, and then cells were treated with $100 \mathrm{nM}$ insulin for $30 \mathrm{~min}$. After treatment with 2-deoxy-[3]-glucose $(0.5 \mu \mathrm{Ci} / \mathrm{mL})$ and 2-deoxy-D-glucose $(100 \mu \mathrm{M})$ for $10 \mathrm{~min}$, the reaction was terminated and glucose uptake activity was measured in lysed cells with a liquid scintillation counter (see Materials and methods). Rosiglitazone $(10 \mu \mathrm{M})$ was used as a positive control for glucose uptake in differentiated C2C12 myotubes. Data are expressed as the mean \pm SEM of three independent experiments. ${ }^{*} P<0.05$ and ${ }^{*} P<0.01$ versus insulin-stimulated glucose uptake in the untreated control

results indicate that the more concentration of these compounds provides the greater ability of glucose uptake.

\section{Comparison of the abilities of BMLE and MLE to increase glucose uptake and insulin secretion}

We compared the abilities of BMLE and MLE to increase glucose uptake in differentiated $\mathrm{C} 2 \mathrm{C} 12$ myotubes and 3 T3-L1 adipocytes and insulin secretion from HIT-T15 pancreatic $\beta$-cells. Insulin-stimulated glucose uptake significantly increased in $\mathrm{C} 2 \mathrm{C} 12$ myotubes treated with 5 or $10 \mu \mathrm{g} / \mathrm{mL}$ BMLE (Fig. 2a). BMLE treatment increased insulin-stimulated glucose uptake from

Table 1 Quantitative analysis of two marker compounds in mulberry leaf extract (MLE) and bioconverted mulberry leaf extract (BMLE). $(n=6)$

\begin{tabular}{|c|c|c|c|}
\hline \multirow[t]{2}{*}{ Compound No } & MLE & BLME & \multirow[t]{2}{*}{ BLME/MLE } \\
\hline & $\begin{array}{l}\text { Conc. } \\
(\mathrm{mg} / \mathrm{g})^{a}\end{array}$ & $\begin{array}{l}\text { Conc. } \\
(\mathrm{mg} / \mathrm{g})^{\mathrm{a}}\end{array}$ & \\
\hline trans-caffeic acid & $0.393 \pm 0.024$ & $0.725 \pm 0.012$ & 1.84 \\
\hline syringaldehyde & $0.206 \pm 0.009$ & $0.577 \pm 0.016$ & 2.80 \\
\hline
\end{tabular}

${ }^{\mathrm{a}}$ Data are represented as average $\pm \mathrm{SD}$
140 to $152 \%$ at a concentration of $5 \mu \mathrm{g} / \mathrm{mL}$ and to $159.1 \%$ at $10 \mu \mathrm{g} / \mathrm{mL}$. By contrast, MLE showed no significant increase in glucose uptake. Neither MLE nor BMLE affected basal glucose uptake. Similarly, $20 \mu \mathrm{g} / \mathrm{mL}$ BMLE significantly increased insulin-stimulated glucose uptake in 3 T3-L1 adipocytes (Fig. 2b). Moreover, the ability of BMLE $(20 \mu \mathrm{g} / \mathrm{mL})$ to increase insulin-stimulated glucose uptake (from 400 to $449.3 \%$ ) was significantly greater than that of MLE (20 $\mu \mathrm{g} / \mathrm{mL}$; from 400 to $420.7 \%)$. As a positive control, rosiglitazone $(10 \mu \mathrm{M})$ significantly increased insulin-stimulated glucose uptake up to $487.9 \%$. Although $20 \mu \mathrm{g} / \mathrm{mL}$ BMLE significantly increased insulin secretion in HIT-T15 pancreatic $\beta$-cells, MLE did not show any stimulating effect (Fig. 2c). As a positive control, glimepiride $(1 \mu \mathrm{g} / \mathrm{mL})$ showed the greatest efficacy in stimulating insulin secretion in this model. These results indicate that bioconversion improved the ability of MLE to increase insulin-stimulated glucose uptake in skeletal muscle cells and adipocytes, as well as insulin secretion in pancreatic $\beta$-cells. BMLE and MLE at greater doses (20 or $50 \mu \mathrm{g} / \mathrm{mL}$ ) than those used in the experiments showed no cytotoxicity for 1 or $2 \mathrm{~h}$ in these cells (In vitro test of the cytotoxicity; Additional file 2). 
A
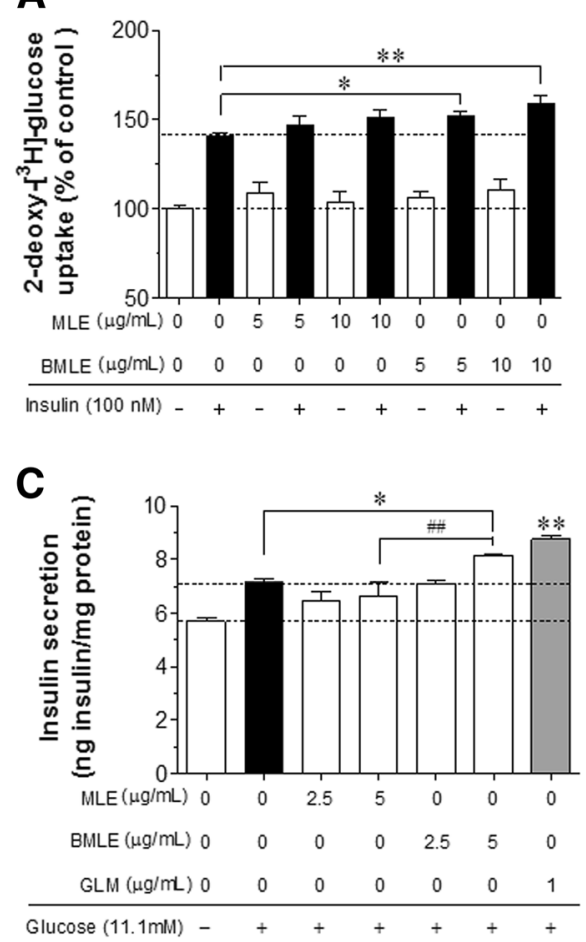

B

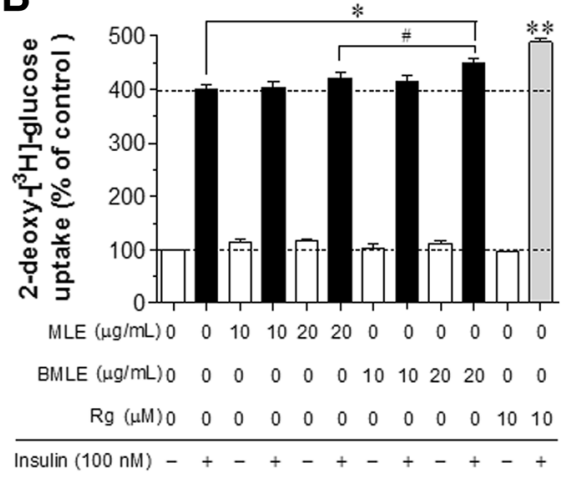

Fig. 2 Comparison of the abilities of bioconverted mulberry leaf extract (BMLE) and unaltered mulberry leaf extract (MLE) to improve glucose uptake and insulin secretion in (a) differentiated C2C12 myotubes, (b) 3 T3-L1 adipocytes, and (c) HIT-T15 pancreatic $\beta$-cells. To measure glucose uptake, cells were incubated in serum-starved DMEM for $1 \mathrm{~h}$ and then, treated with MLE, BMLE or rosiglitazone (Rg) for $1 \mathrm{~h}$. The medium was changed to Krebs-Ringer phosphate-HEPES buffer containing the prescribed concentrations of MLE, BMLE or Rg for 30 min and then treated with $100 \mathrm{nM}$ insulin for $30 \mathrm{~min}$. After treatment with 2-deoxy-[ $\left.{ }^{3} \mathrm{H}\right]$-glucose $(0.5 \mu \mathrm{Ci} / \mathrm{mL})$ and 2-deoxy-D-glucose $(100 \mu \mathrm{M})$ for $10 \mathrm{~min}$, the reaction was terminated and glucose uptake activity was measured in lysed cells with a liquid scintillation counter (see Materials and methods). To measure insulin secretion, cells incubated with Krebs-Ringer bicarbonate-HEPES buffer containing $0.3 \%$ bovine serum albumin for 30 min were treated with $11.1 \mathrm{mM}$ glucose and MLE, BMLE or glimepiride (GLM) for $1 \mathrm{~h}$ and the insulin concentration released into the media was measured (see Materials and Methods). $\mathrm{Rg}(10 \mu \mathrm{M})$ and $\mathrm{GLM}(1 \mu \mathrm{g} / \mathrm{mL})$ were used as positive controls for glucose uptake in differentiated C2C12 myotubes and 3 T3-L1 adipocytes and insulin release in HIT-T15 pancreatic $\beta$-cells, respectively. Data are expressed as the mean \pm SEM of three independent experiments. ${ }^{*} P<0.05$ and ${ }^{*} P<0.01$ versus insulin-stimulated glucose uptake or glucose-stimulated insulin release in the untreated control; $\# P<0.05$ and ${ }^{\# \#} P<0.01$ versus insulin-stimulated glucose uptake or glucose-stimulated insulin release in the MLE-treated group

The effect of BMLE, MLE and two marker compounds on AKT phosphorylation in $\mathrm{C} 2 \mathrm{C} 12$ myotubes

Insulin-mediated AKT phosphorylation induces GLUT4 translocation from cytosol to membrane, enhancing glucose uptake [40, 41]. To confirm this linkage, the effect of two marker compounds, MLE and BMLE on AKT phosphorylation was measured in $\mathrm{C} 2 \mathrm{C} 12$ myotubes (Fig. 3). Trans-caffeic acid significantly increased AKT phosphorylation (Fig. 3a). Syringaldehyde did not show any statistical significant increase at given concentrations, but exert an increasing tendency. As expected, both BMLE and MLE significantly increased AKT phosphorylation (Fig. 3b). Notably, BMLE had a greater effect on AKT phosphorylation than MLE at the same concentration $(10 \mu \mathrm{g} / \mathrm{mL})$. These results suggest that bioconversion increase in amount of trans-caffeic acid, which causes the greater effect than MLE on AKT phosphorylation-induced glucose uptake.
Improvement of glucose tolerance in obese diabetic mice by BMLE and MLE treatment

To compare the abilities of BMLE and MLE to improve glucose tolerance, obese diabetic mice were established by co-administering STZ and NA as described previously $[28,29]$. The body weights of both BMLE- and MLE-treated mice fed a high-fat diet decreased (Fig. 4a). As a positive control, metformin $(300 \mathrm{mg} / \mathrm{kg}$, PO) treatment also resulted in a decrease in body weight. However, fasting blood glucose levels measured once a week were significantly decreased in both the BMLE $(600 \mathrm{mg} / \mathrm{kg}$, PO)- and metformin-treated groups (Fig. 4b). Note that the quantities of two marker compounds in BMLE dosage is greater than those in MLE dosage (Table 2).

The oral glucose tolerance test (OGTT) was performed after 6 weeks of treatment, and the results were plotted with a line graph, using the area under the curve (AUC) of each line to compare the differences among 


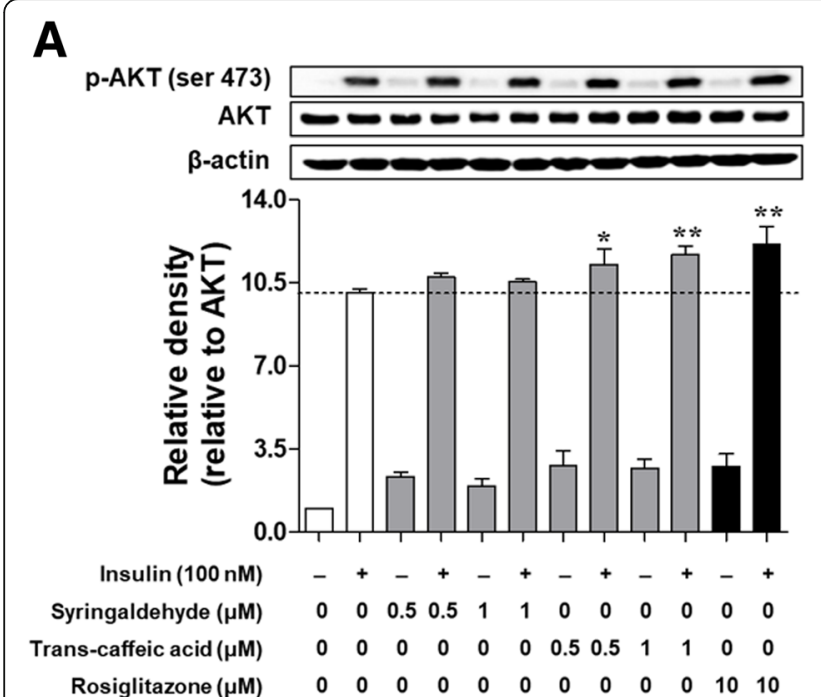

B

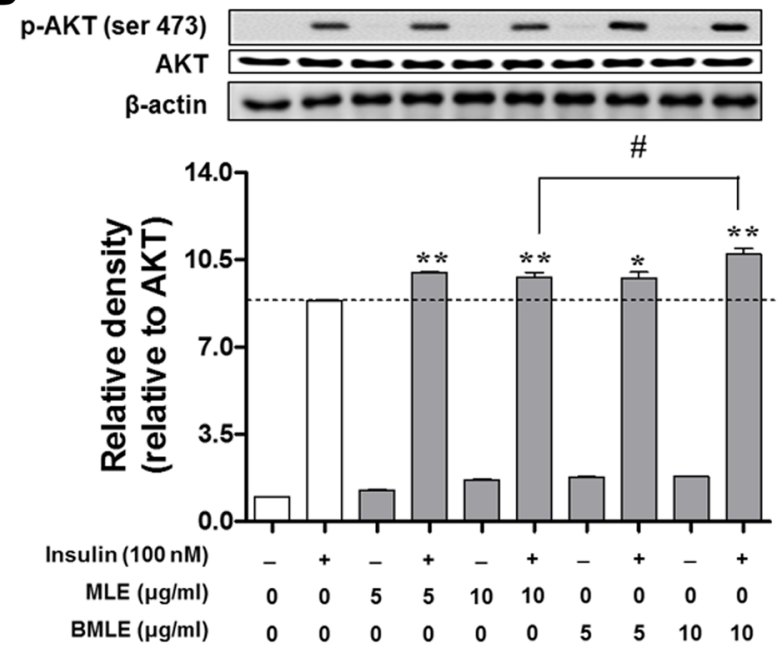

Fig. 3 Effect of two marker compounds (a) and unaltered mulberry leaf extract (MLE) and bioconverted mulberry leaf extract (BMLE) (b) on AKT phosphorylation in insulin-stimulated C2C12 myotubes. Cells were incubated in serum-starved DMEM for $1 \mathrm{~h}$ and then treated with two marker compounds, MLE, BMLE, or rosiglitazone as a positive control for $1 \mathrm{~h}$. The medium was changed to Krebs-Ringer phosphate-HEPES buffer containing two marker compounds, MLE, BMLE or rosiglitazone for $30 \mathrm{~min}$. Thereafter, $100 \mathrm{nM}$ insulin was treated for $30 \mathrm{~min}$. Cells were lysed and proteins were employed by SDS-PAGE followed by Western blotting using primary antibodies targeting anti-phospho AKT, AKT and $\beta$-actin. The data depicted in bar graph expressed as the means \pm SEM are an average of three similar and independent experiments and gel images are of representative blots. ${ }^{*} P<0.05$ and ${ }^{* *} P<0.01$ versus insulin-stimulated cells with no treatment; ${ }^{*} P<0.05$ versus insulin-stimulated cells treated with MLE

treatments (Fig. 5a). Both the BMLE- and MLE-treated groups showed significantly decreased blood glucose levels compared to the control (untreated obese diabetic mice fed a high-fat diet). The blood glucose levels in the BMLE-treated group were lower than those in the MLE-treated group at the same dose. The insulin tolerance test (ITT) was performed after 7 weeks of treatment, and significant changes among groups were compared based on the AUC (Fig. 5b). After injecting insulin, blood glucose levels in both the BMLE- and MLE-treated groups were significantly lower than those in the control group. Moreover, the AUC was significantly lower in the $600 \mathrm{mg} / \mathrm{kg}$ BMLE-treated group than in the $600 \mathrm{mg} / \mathrm{kg}$ MLE-treated group. In both tests, the AUCs of metformin were similar to those of the high concentration-treated BMLE group. These results indicate that BMLE had a better ability to regulate blood glucose levels in the obese diabetic animal model than MLE.

\section{Regulation of $\mathrm{HbA}_{1 \mathrm{C}}$ levels and insulin plasma levels by BLME and MLE}

After the final BMLE and MLE treatment in mice, $\mathrm{HbA}_{1 \mathrm{C}}$ blood and plasma insulin levels were measured. The $\mathrm{HbA}_{1 \mathrm{C}}$ levels in both the BMLE- and MLE-treated groups were significantly lower than those in the control group (Fig. 6a). As expected, the $\mathrm{HbA}_{1 \mathrm{C}}$ levels in the BMLE-treated group were significantly lower than those of the MLE-treated group at the same dosage. Plasma insulin levels were significantly increased in only the group treated with $600 \mathrm{mg} /$ kg BMLE (Fig. 6b). Next, the homeostasis model assessment of insulin resistance (HOMA-IR) and quantitative insulin sensitivity check index (QUICKI) values were compared among the groups (for the calculations, see the Materials and Methods). The HOMA-IR value in the 600 $\mathrm{mg} / \mathrm{kg}$ BMLE-treated group was significantly lower than that in the MLE group, but was similar to that in the metformin-treated group (Fig. 7a). Moreover, the QUICKI value of the $600 \mathrm{mg} / \mathrm{kg}$ BMLE-treated group was higher than that of the MLE group (Fig. 7b). These results indicate that BMLE showed a better capacity than MLE to decrease blood $\mathrm{HbA}_{1 \mathrm{C}}$ levels, increase insulin secretion, and improve insulin resistance and insulin sensitivity.

\section{Discussion}

We investigated the differences in the pharmacological efficacies of BMLE and MLE. Bioconversion process provides the more quantities of two marker compounds, trans-caffeic acid and syringaldehyde, and these two compounds have an ability to increase glucose uptake in C2C12 myotubes in a dose-dependent manner. Syringaldehyde has been known to increase glucose uptake in rat L6 myocytes [42] and GLUT-4 expression in skeletal muscles isolated from STZ-induced diabetic rats [43]. Previous reports showed that caffeic acid enhanced glucose uptake in tumor necrosis factor $\alpha$-treated insulin-resistant FL83B cells [44] and human skeletal muscle cells (SkMC C-12580) [45], and increased insulin secretion in rat insulinoma cells (INS-1E) [45]. At the cellular level, BMLE was 


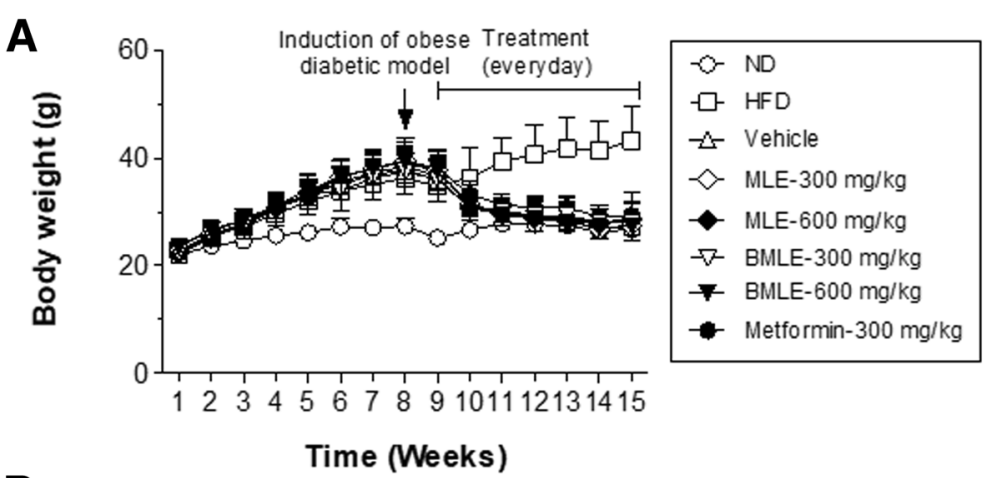

B

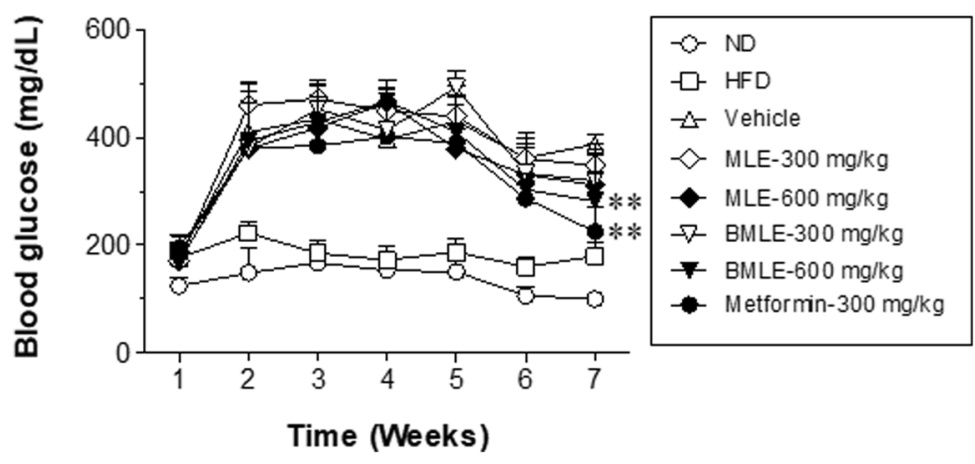

Fig. 4 Effects of bioconverted mulberry leaf extract (BMLE) compared to unaltered mulberry leaf extract (MLE) on the body weight and blood glucose levels of obese diabetic mice. Obese diabetic mice were produced by feeding on high-fat diet (HFD) for 8 weeks into six-week-old C57BL/6 mice and then (at the beginning of 9th week) injecting streptozotocin with nicotinamide (see Materials and methods). After checking for high blood glucose, mice were orally administered with MLE (300 and $600 \mathrm{mg} / \mathrm{kg}$ ) or BMLE (300 and $600 \mathrm{mg} / \mathrm{kg}$ ) for 7 weeks and the changes in (a) body weight and (b) blood glucose level were examined. Metformin $(300 \mathrm{mg} / \mathrm{kg}$ ) was used as a positive control. Data are expressed as the mean $\pm \operatorname{SEM}(n=7)$. ${ }^{*} P<0.01$ versus blood glucose levels in vehicle-control mice

more effective than MLE in increasing glucose uptake into skeletal muscle cells and adipocytes, increasing insulin secretion in pancreatic $\beta$-cells and lowering blood glucose. In a diabetic animal model, BMLE more effectively controlled fasting blood glucose and insulin levels than MLE. Therefore, our results demonstrate that bioconversion can increase the pharmacological efficacy of MLE, which may be due to the greater concentration of two marker compounds in BMLE.

Previous reports have shown that MLE stimulates glucose uptake in rat adipocytes [46] and significantly lowers fasting plasma glucose and increases insulin secretion in STZ-induced diabetic rats [47]. Consistent

Table 2 The total quantities of two marker compounds in injected doses of mulberry leaf extract (MLE) and bioconverted mulberry leaf extract (BMLE) in animal experiments

\begin{tabular}{llll}
\hline Compounds & Dosage & $\begin{array}{l}\text { MLE } \\
(\mathrm{mg})\end{array}$ & $\begin{array}{l}\text { BLME } \\
(\mathrm{mg})\end{array}$ \\
\hline trans-caffeic acid & $300 \mathrm{mg} / \mathrm{kg}$ & 0.1179 & 0.2175 \\
& $600 \mathrm{mg} / \mathrm{kg}$ & 0.2358 & 0.435 \\
syringaldehyde & $300 \mathrm{mg} / \mathrm{kg}$ & 0.0618 & 0.1236 \\
& $600 \mathrm{mg} / \mathrm{kg}$ & 0.1236 & 0.3462 \\
\hline
\end{tabular}

with previous reports, our observations (Fig. 2a, b) revealed that both BMLE and MLE increased glucose uptake into $\mathrm{C} 2 \mathrm{C} 12$ myotubes and $3 \mathrm{~T} 3-\mathrm{L} 1$ adipocytes; however, BMLE exhibited greater pharmacological efficacy than MLE. Moreover, the ability of BMLE to increase insulin secretion from pancreatic $\beta$-cells was greater than that of MLE (Fig. 2c). Moreover, both BMLE and MLE have an ability to significantly increase AKT phosphorylation in C2C12 myotubes (Fig. 3). Since BMLE has a greater effect on AKT phosphorylation than MLE at the same concentration, BMLE is superior to increase glucose uptake than MLE. These in vitro results indicate that BMLE is more effective for controlling blood glucose levels than MLE at the same concentration.

Normalization of blood glucose levels is important for the management of diabetes, and some herbal remedies are effective for improving hyperglycemia. MLE has been shown to reduce fasting blood glucose and blood $\mathrm{HbA}_{1 \mathrm{C}}$ levels in STZ-induced diabetic rats by attenuating non-esterified fatty acid (NEFA) signaling and modulating intestinal microflora [13]. In this study using a diabetic animal model induced with a previously described method [28], BMLE significantly reduced fasting blood glucose levels (Fig. 4b), while effectively controlling 


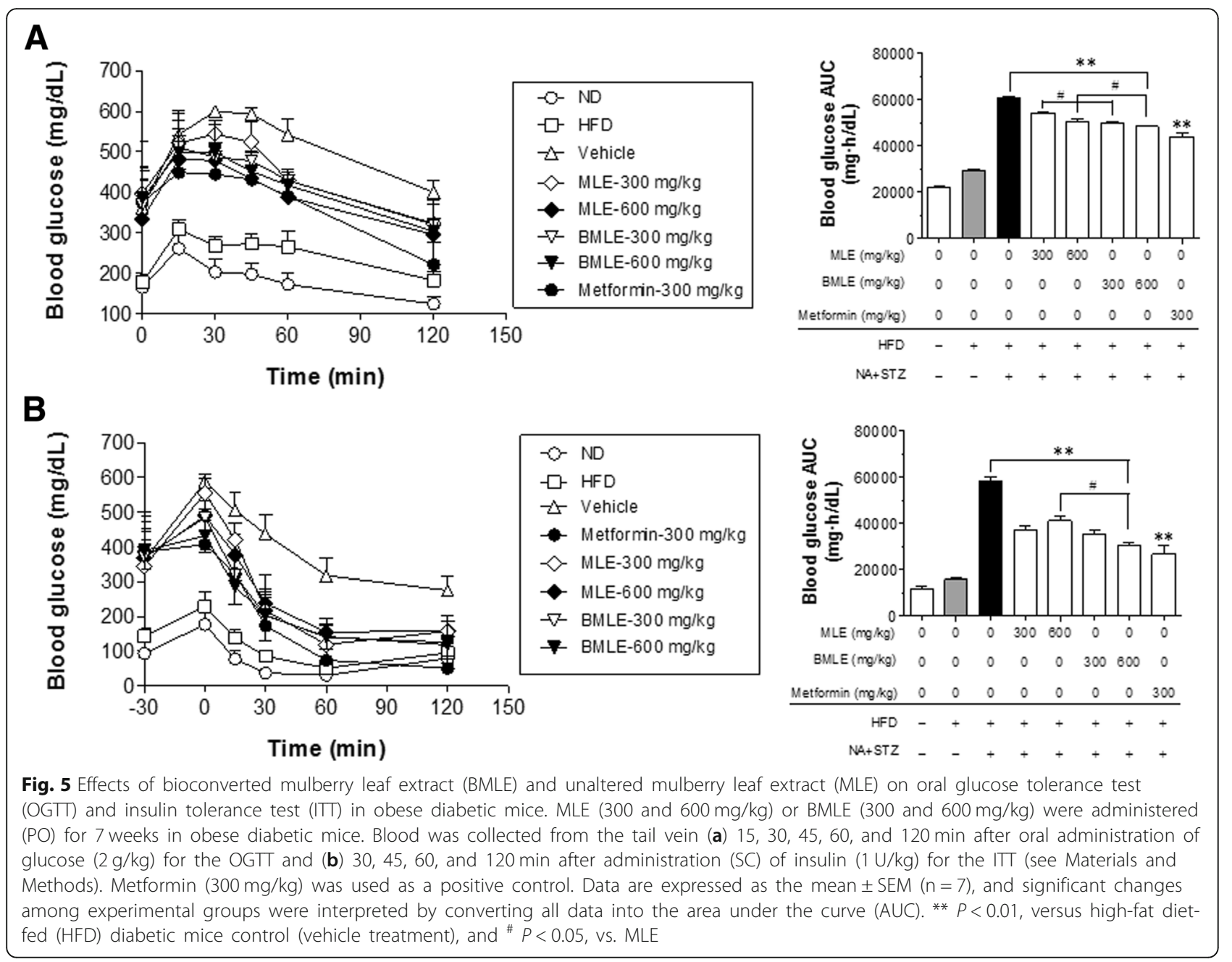

blood glucose after administration of high glucose (Fig. 5a) and normalizing insulin function under high-glucose conditions (Fig. 5b). Compared to MLE, BMLE yielded greater effects at the same concentration. Moreover, both BMLE and MLE treatment significantly reduced blood levels of $\mathrm{HbA}_{1 \mathrm{C}}$, which were formed under hyperglycemic conditions [48], although the ability of BMLE to decrease $\mathrm{HbA}_{1 \mathrm{C}}$ blood levels was greater than that of MLE (Fig. 6a). Because type 2 diabetes causes the destruction of pancreatic $\beta$-cells via oxidative stress and decreases insulin secretion [49], the ability of high-fat-diet-fed diabetic mice to secret insulin was reduced, and the high concentration of BMLE $(600 \mathrm{mg} / \mathrm{kg})$ significantly restored insulin secretion (Fig. 6b). Taken together, BMLE can more effectively regulate blood glucose levels and restore insulin secretion in diabetic mice, leading to a decrease in $\mathrm{HbA}_{1 \mathrm{C}}$ levels in blood.

Improvements in insulin resistance [50] and insulin sensitivity [51] are the most important therapeutic parameter in patients with type 2 diabetes. HOMA-IR and
QUICKI are commonly used as indicators of insulin resistance and $\beta$-cell function and of insulin sensitivity, respectively. Although both BMLE and MLE tended to improve the HOMA-IR and QUICKI indices, only the high concentration of BMLE showed a significant decrease in HOMA-IR (Fig. 7a) and increase in QUICKI (Fig. 7b) indices, which indicates that the high concentration of BMLE significantly improved insulin resistance and insulin sensitivity. Therefore, BMLE offers superior control of hyperglycemia and improvements in insulin resistance and insulin sensitivity than MLE, which suggests that bioconversion may be an important process for maximizing the pharmacological efficacy of natural product extracts.

\section{Conclusions}

In this study, we examined the ability of BMLE to increase glucose uptake in $\mathrm{C} 2 \mathrm{C} 12$ myotubes and $3 \mathrm{~T} 3-\mathrm{L} 1$ adipocytes, as well as insulin secretion in HIT-T15 pancreatic $\beta$-cells. Compared to MLE, treatment with BMLE in diabetic mice resulted in the improved ability to 

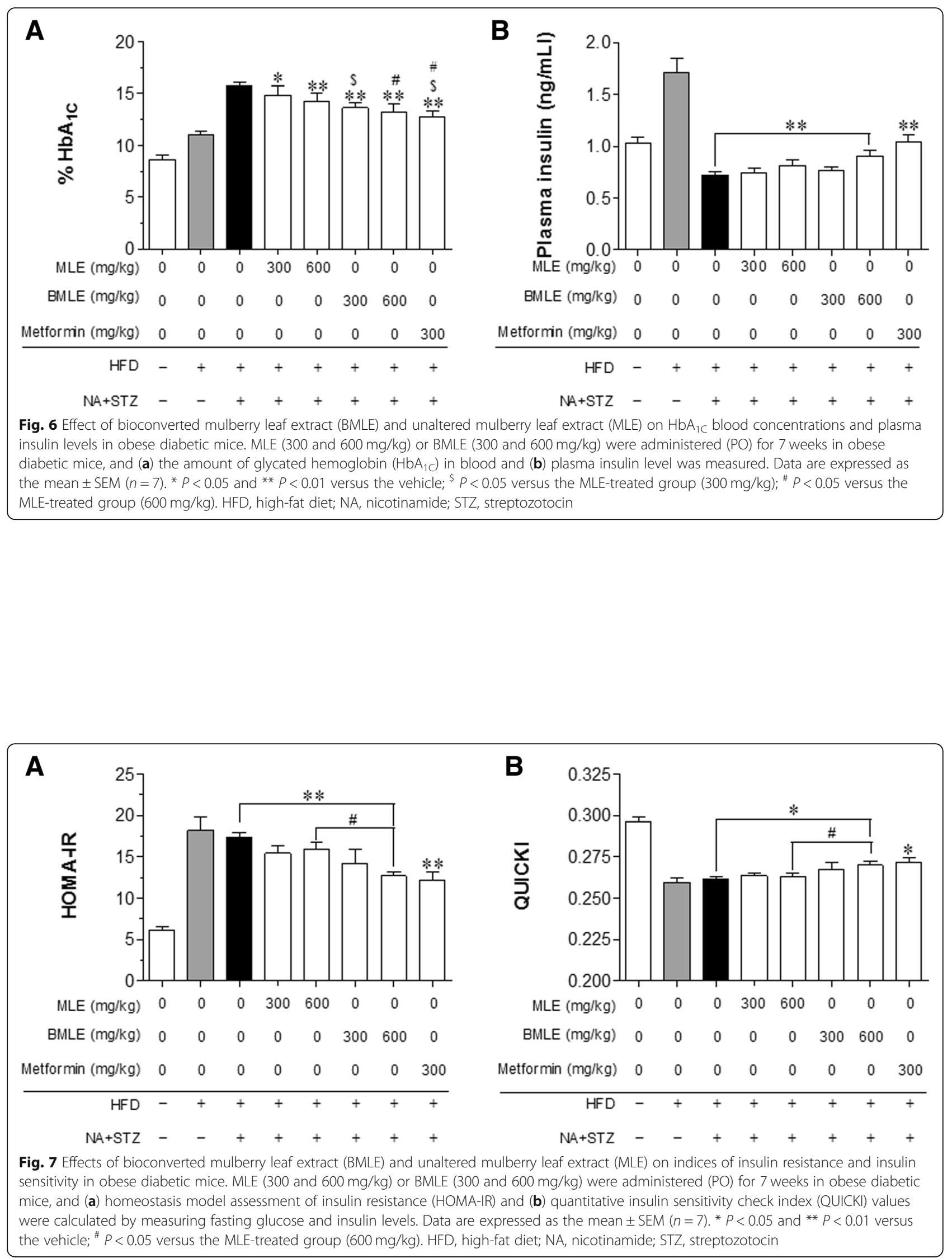
decrease fasting blood glucose levels, tolerate glucose, decrease blood $\mathrm{HbA}_{1 \mathrm{C}}$ levels, and increase plasma insulin, leading to the amelioration of insulin resistance and insulin sensitivity. Taken together, these results indicate that BMLE is superior to MLE in the management of diabetic condition, which suggests that bioconversion can be used as a useful tool for increasing the active ingredients in MLE.

\section{Additional files}

Additional file 1: The following information is available online: Grouping experimental animals by results of blood glucose levels and oral glucose tolerance test. (PDF $1658 \mathrm{~kb}$ )

Additional file 2: The following information is available online: In vitro test of the cytotoxicity of the bioconverted and unaltered mulberry lead extracts (BMLE and MLE, respectively) used in this study. (PDF $1633 \mathrm{~kb}$ )

\section{Abbreviations}

AUC: Area under the curve; BMLE: Bioconverted mulberry leaf extract; DMEM: Dulbecco's modified eagle medium; FBS: Fetal bovine serum; $\mathrm{HbA}_{1}$ : Glycated hemoglobin; HFD: High-fat diet; HOMA-IR: Homeostasis model assessment of insulin resistance; ITT: Insulin tolerance test; KRBH: Krebs-ringer bicarbonate-HEPES; MLE: Mulberry leaf extract; NA: Nicotinamide; NEFA: Non-esterified fatty acid; OGTT: Oral glucose tolerance test; PBS: Phosphate-buffered saline; QUICKI: Quantitative insulin sensitivity check index; STZ: Streptozotocin

\section{Acknowledgements}

The work was supported by the Korea Institute of Planning and Evaluation for Technology in Food, Agriculture, Forestry through the Agri-Bio Industry Technology Development Program, funded by the Ministry of Agriculture, Food and Rural Affairs (No. 315024-03-3-SB040).

\section{Funding}

This study was funded by the Korea Institute of Planning and Evaluation for Technology in Food, Agriculture, Forestry through the Agri-Bio Industry Technology Development Program, funded by the Ministry of Agriculture, Food and Rural Affairs (No. 315024-03-3-SB040).

\section{Availability of data and materials}

The data are available from the authors upon reasonable request.

\section{Authors' contributions}

S.-H.J, and C.-S.M conceived and designed the experiments; S.-H.J, J.-H.H, H.-S.P, and D.-H.L performed the experiments; H.S.C, S.J.K and J.S.K performed extraction and HPLC analysis; C.-S.M analyzed the data; J.S.K, and C.-S.M contributed reagents/materials/analysis tools; S.-H.J, and C.-S.M wrote the paper.

\section{Ethics approval and consent to participate}

All the experimental procedures were performed according to the guidelines of the Committee for Ethical Usage of Experimental Animals at Chungnam National University (CNU-00773; Daejeon, South Korea).

\section{Consent for publication}

Not applicable.

\section{Competing interests}

The authors declare that they have no competing interests.

\section{Publisher's Note}

Springer Nature remains neutral with regard to jurisdictional claims in published maps and institutional affiliations.

\section{Author details}

${ }^{1}$ Department of Pharmacology, Chungnam National University College of Pharmacy, 99 Daehak-ro (St.), Yuseong-gu, Daejeon 34134, Republic of Korea. ${ }^{2}$ MSC Annexed Food Technology Research Institute, Yangsan-si,

Gyeongsangnam-do 50518, Republic of Korea.

Received: 26 August 2018 Accepted: 15 February 2019

Published online: 06 March 2019

\section{References}

1. Zeng Q, Chen H, Zhang C, Han M, Li T, Qi X, et al. Definition of eight mulberry species in the genus Morus by internal transcribed spacer-based phylogeny. PLoS One. 2015;10(8):e0135411. https://doi.org/10.1371/journal. pone.0135411.

2. Chan EW, Lye PY, Wong SK. Phytochemistry, pharmacology, and clinical trials of Morus alba. Chin J Nat Med. 2016;14(1):17-30. https://doi.org/10. 3724/SP.J.1009.2016.00017.

3. Naowaboot J, Pannangpetch P, Kukongviriyapan V, Kukongviriyapan U, Nakmareong $S$, Itharat A. Mulberry leaf extract restores arterial pressure in streptozotocin-induced chronic diabetic rats. Nutr Res. 2009;29(8):602-8. https://doi.org/10.1016/j.nutres.2009.06.002.

4. Valacchi G, Belmonte G, Miracco C, Eo H, Lim Y. Effect of combined mulberry leaf and fruit extract on liver and skin cholesterol transporters in high fat diet-induced obese mice. Nutr Res Pract. 2014;8(1):20-6. https://doi. org/10.4162/nrp.2014.8.1.20.

5. Kim DS, Ji HD, Rhee MH, Sung YY, Yang WK, Kim SH, et al. Antiplatelet activity of Morus alba leaves extract, mediated via inhibiting granule secretion and blocking the phosphorylation of extracellular-signal-regulated kinase and akt. Evid Based Complement Alternat Med. 2014;2014(639548). https://doi.org/10.1155/2014/639548.

6. Liao BY, Zhu DY, Thakur K, Li L, Zhang JG, Wei ZJ. Thermal and antioxidant properties of polysaccharides sequentially extracted from mulberry leaves (Morus alba L.). Molecules. 2017;22(12). https://doi.org/10.3390/ molecules22122271.

7. Ann JY, Eo H, Lim Y. Mulberry leaves (Morus alba L.) ameliorate obesityinduced hepatic lipogenesis, fibrosis, and oxidative stress in high-fat diet-fed mice. Genes Nutr. 2015;10(6):46. https://doi.org/10.1007/s12263-015-0495-x.

8. Lim HH, Lee SO, Kim SY, Yang SJ, Lim Y. Anti-inflammatory and antiobesity effects of mulberry leaf and fruit extract on high fat diet-induced obesity. Exp Biol Med. 2013;238(10):1160-9. https://doi.org/10.1177/ 1535370213498982

9. Xu J, Wang X, Cao K, Dong Z, Feng Z, Liu J. Combination of $\beta$-glucan and Morus alba $\mathrm{L}$. leaf extract promotes metabolic benefits in mice fed a highfat diet. Nutrients. 2017;9(10). https://doi.org/10.3390/nu9101110.

10. Mudra M, Ercan-Fang N, Zhong L, Furne J, Levitt M. Influence of mulberry leaf extract on the blood glucose and breath hydrogen response to ingestion of $75 \mathrm{~g}$ sucrose by type 2 diabetic and control subjects. Diabetes Care. 2007;30(5):1272-4

11. Riche DM, Riche KD, East HE, Barrett EK, May WL. Impact of mulberry leaf extract on type 2 diabetes (Mul-DM): a randomized, placebo-controlled pilot study. Complement Ther Med. 2017;32:105-8. https://doi.org/10.1016/j.ctim. 2017.04.006.

12. Ranjan B, Kumar R, Verma N, Mittal S, Pakrasi PL, Kumar RV. Evaluation of the antidiabetic properties of S-1708 mulberry variety. Pharmacogn Mag. 2017; 13(Suppl 2):S280-S8. https://doi.org/10.4103/pm.pm_490_16.

13. Sheng Y, Zheng S, Ma T, Zhang C, Ou X, He X, et al. Huang K. Mulberry leaf alleviates streptozotocin-induced diabetic rats by attenuating NEFA signaling and modulating intestinal microflora. Sci Rep. 2017;7(1):12041. https://doi.org/10.1038/s41598-017-12245-2.

14. Wang $\mathrm{HJ}$, Chiang $\mathrm{BH}$. Anti-diabetic effect of a traditional Chinese medicine formula. Food Funct. 2012;3(11):1161-9. https://doi.org/10.1039/c2fo30139c.

15. Hunyadi A, Martins A, Hsieh TJ, Seres A, Zupko I. Chlorogenic acid and rutin play a major role in the in vivo anti-diabetic activity of Morus alba leaf extract on type II diabetic rats. PLoS One. 2012;7(11):e50619. https://doi.org/ 10.1371/journal.pone.0050619. Epub 2012 Nov 21.

16. Bae UJ, Jung ES, Jung SJ, Chae SW, Park BH. Mulberry leaf extract displays antidiabetic activity in $d b / d b$ mice via akt and AMP-activated protein kinase phosphorylation. Food Nutr Res. 2018;62. https://doi.org/10.29219/fnr.v62. 1473 eCollection 2018

17. Anson NM, Selinheimo E, Havenaar R, Aura AM, Mattila I, Lehtinen P, et al. Bioprocessing of wheat bran improves in vitro bioaccessibility and colonic 
metabolism of phenolic compounds. J Agric Food Chem. 2009;57(14):614855. https://doi.org/10.1021/jf900492h.

18. Hong YH, Jung EY, Park Y, Shin KS, Kim TY, Yu KW, et al. Enzymatic improvement in the polyphenol extractability and antioxidant activity of green tea extracts. Biosci Biotechnol Biochem. 2013;77(1):22-9.

19. Lim H, Yeo E, Song E, Chang YH, Han BK, Choi HJ, et al. Bioconversion of Citrus unshiu peel extracts with cytolase suppresses adipogenic activity in 3T3-L1 cells. Nutr Res Pract. 2015;9(6):599-605. https://doi.org/10.4162/nrp.2015.9.6.599.

20. Kwon DY, Daily JW 3rd, Kim HJ, Park S. Antidiabetic effects of fermented soybean products on type 2 diabetes. Nutr Res. 2010;30(1):1-13. https://doi. org/10.1016/j.nutres.2009.11.004.

21. Lee SY, Park SL, Hwang JT, Yi SH, Nam YD, Lim SI. Antidiabetic effect of Morinda citrifolia (noni) fermented by Cheonggukjang in KK-Ay diabetic mice. Evid Based Complement Alternat Med. 2012;2012:163280. https://doi.org/10. 1155/2012/163280

22. Oh MR, Park SH, Kim SY, Back HI, Kim MG, Jeon JY, et al. Postprandial glucose-lowering effects of fermented red ginseng in subjects with impaired fasting glucose or type 2 diabetes: a randomized, double-blind, placebo-controlled clinical trial. BMC Complement Altern Med. 2014;14(237). https://doi.org/10.1186/1472-6882-14-237.

23. Sanchez-Magana LM, Cuevas-Rodriguez EO, Gutierrez-Dorado R, AyalaRodriguez AE, Valdez-Ortiz A, Milan-Carrillo J, et al. Solid-state bioconversion of chickpea (Cicer arietinum L.) by Rhizopus oligosporus to improve total phenolic content, antioxidant activity and hypoglycemic functionality. Int J Food Sci Nutr. 2014;65(5):558-64. https://doi.org/10.3109/09637486.2014.893284.

24. Zheng HZ, Hwang IW, Chung SK. Enhancing polyphenol extraction from unripe apples by carbohydrate-hydrolyzing enzymes. J Zhejiang Univ Sci B. 2009;10(12):912-9. https://doi.org/10.1631/jzus.B0920186.

25. Islam MS, Loots d T. Experimental rodent models of type 2 diabetes: a review. Methods Find Exp Clin Pharmacol. 2009;31(4):249-61. https://doi. org/10.1358/mf.2009.31.4.1373958.

26. Tahara A, Matsuyama-Yokono A, Shibasaki M. Effects of antidiabetic drugs in high-fat diet and streptozotocin-nicotinamide-induced type 2 diabetic mice. Eur J Pharmacol. 2011;655(1-3):108-16. https://doi.org/10.1016/.ejphar.2011.01.015.

27. Liu M, Zhang Y, Zhang H, Hu B, Wang L, Qian H, et al. The anti-diabetic activity of oat $\beta$-D-glucan in streptozotocin-nicotinamide induced diabetic mice. Int J Biol Macromol. 2016;91:1170-6. https://doi.org/10.1016/j.jibiomac. 2016.06.083.

28. Choi WS, Lee JJ, Kim Y, Kim IS, Zhang WY, Myung CS. Synergistic improvement in insulin resistance with a combination of fenofibrate and rosiglitazone in obese type 2 diabetic mice. Arch Pharm Res. 2011;34(4): 615-24. https://doi.org/10.1007/s12272-011-0412-9.

29. Nan MH, Park JS, Myung CS. Construction of adiponectin-encoding plasmid DNA and gene therapy of non-obese type 2 diabetes mellitus. J Drug Target. 2010;18(1):67-77. https://doi.org/10.3109/10611860903225719.

30. Watala C, Kazmierczak P, Dobaczewski M, Przygodzki T, Bartus M, Lomnicka $M$, et al. Anti-diabetic effects of 1-methylnicotinamide (MNA) in streptozocin-induced diabetes in rats. Pharmacol Rep. 2009;61(1):86-98.

31. American Diabetes A. 2. Classification and diagnosis of diabetes. Diabetes Care. 2017;40(Suppl 1):S11-24. https://doi.org/10.2337/dc15-S005.

32. Roden M. Diabetes mellitus: definition, classification and diagnosis. Wien Klin Wochenschr. 2016;28(Suppl 2):S37-40. https://doi.org/10.1007/s00508015-0931-3.

33. Tahara A, Kurosaki E, Yokono M, Yamajuku D, Kihara R, Hayashizaki Y, et al. Antidiabetic effects of SGLT2-selective inhibitor ipragliflozin in streptozotocinnicotinamide-induced mildly diabetic mice. J Pharmacol Sci. 2012;120(1):36-44.

34. Kim JK, Lim Y, Lee JO, Lee YS, Won NH, Kim H, et al. PRMT4 is involved in insulin secretion via the methylation of histone $\mathrm{H} 3$ in pancreatic $\beta$-cells. J Mol Endocrinol. 2015;54(3):315-24. https://doi.org/10.1530/JME-14-0325.

35. Thrailkill KM, Nyman JS, Bunn RC, Uppuganti S, Thompson KL, Lumpkin CK $\mathrm{Jr}$, et al. The impact of SGLT2 inhibitors, compared with insulin, on diabetic bone disease in a mouse model of type 1 diabetes. Bone. 2017:94:141-51. https://doi.org/10.1016/j.bone.2016.10.026.

36. Han JH, Zhou W, Li W, Tuan PQ, Khoi NM, Thuong PT, et al. Pentacyclic triterpenoids from Astilbe rivularis that enhance glucose uptake via the activation of akt and erk1/2 in C2C12 myotubes. J Nat Prod. 2015;78(5): 1005-14. https://doi.org/10.1021/np5009174.

37. Han JH, Kim IS, Jung SH, Lee SG, Son HY, Myung CS. The effects of propionate and valerate on insulin responsiveness for glucose uptake in 3T3-L1 adipocytes and C2C12 myotubes via G protein-coupled receptor 41 . PLoS One. 2014;9(4):e95268. https://doi.org/10.1371/journal.pone.0095268.
38. Jung SH, Han JH, Park HS, Lee JJ, Yang SY, Kim YH, et al. Inhibition of collagen-induced platelet aggregation by the secobutanolide secolincomolide A from Lindera obtusiloba Blume. Front Pharmacol. 2017;8: 560. https://doi.org/10.3389/fphar.2017.00560.

39. Park HS, Quan KT, Han JH, Jung SH, Lee DH, Jo E, et al. Rubiarbonone C inhibits platelet-derived growth factor-induced proliferation and migration of vascular smooth muscle cells through the focal adhesion kinase, MAPK and STAT3 Tyr705 signalling pathways. Br J Pharmacol. 2017;174(22):414054. https://doi.org/10.1111/bph.13986

40. Fang P, Yu M, Zhang L, Wan D, Shi M, Zhu Y, et al. Baicalin against obesity and insulin resistance through activation of AKT/AS160/GLUT4 pathway. Mol Cell Endocrinol. 2017;448:77-86. https://doi.org/10.1016/j.mce.2017.03. 027.

41. Sato M, Dehvari N, Oberg Al, Dallner OS, Sandström AL, Olsen JM, et al. Improving type 2 diabetes through a distinct adrenergic signaling pathway involving $\mathrm{mTORC2}$ that mediates glucose uptake in skeletal muscle. Diabetes. 2014;63(12):4115-29. https://doi.org/10.2337/db13-1860.

42. Huang $\mathrm{CH}$, Chen MF, Chung HH, Cheng JT. Antihyperglycemic effect of syringaldehyde in streptozotocin-induced diabetic rats. J Nat Prod. 2012 75(8):1465-8. https://doi.org/10.1021/np3003723.

43. Kuo SC, Chung HH, Huang CH, Cheng JT. Decrease of hyperglycemia by syringaldehyde in diabetic rats. Horm Metab Res. 2014;46(1):8-13. https:// doi.org/10.1055/s-0033-1351274.

44. Huang DW, Shen SC. WU JS. Effects of caffeic acid and cinnamic acid on glucose uptake in insulin-resistant mouse hepatocytes. J Agric Food Chem. 2009:57(17):7687-92. https://doi.org/10.1021/j901376x.

45. Mellbye FB, Jeppesen PB, Hermansen K, Gregersen S. Cafestol, a bioactive substance in coffee, stimulates insulin secretion and increases glucose uptake in muscle cells: studies in vitro. J Nat Prod. 2015;78(10):2447-51. https://doi.org/10.1021/acs.jnatprod.5b00481.

46. Naowaboot J, Pannangpetch P, Kukongviriyapan V, Prawan A, Kukongviriyapan U, Itharat A. Mulberry leaf extract stimulates glucose uptake and GLUT4 translocation in rat adipocytes. Am J Chin Med. 2012; 40(1):163-75.

47. Huang SS, Yan YH, Ko CH, Chen KM, Lee SC, Liu CT. A comparison of foodgrade folium mori extract and 1-deoxynojirimycin for glycemic control and renal function in streptozotocin-induced diabetic rats. J Tradit Complement Med. 2014;4(3):162-70. https://doi.org/10.4103/2225-4110.13163.

48. Higgins T. HbA1c for screening and diagnosis of diabetes mellitus. Endocrine. 2013;43(2):266-73. https://doi.org/10.1007/s12020-012-9768-y.

49. Hasnain SZ, Prins JB, McGuckin MA. Oxidative and endoplasmic reticulum stress in $\beta$-cell dysfunction in diabetes. J Mol Endocrinol. 2016;56(2):R33-54. https://doi.org/10.1530/JME-15-0232.

50. Matthews DR, Hosker JP, Rudenski AS, Naylor BA, Treacher DF, Turner RC. Homeostasis model assessment: insulin resistance and $\beta$-cell function from fasting plasma glucose and insulin concentrations in man. Diabetologia. 1985;28(7):412-9.

51. Katz A, Nambi SS, Mather K, Baron AD, Follmann DA, Sullivan G, et al. Quantitative insulin sensitivity check index: a simple, accurate method for assessing insulin sensitivity in humans. J Clin Endocrinol Metab. 2000; 85(7):2402-10
Ready to submit your research? Choose BMC and benefit from:
- fast, convenient online submission
- thorough peer review by experienced researchers in your field
- rapid publication on acceptance
- support for research data, including large and complex data types
- gold Open Access which fosters wider collaboration and increased citations
- maximum visibility for your research: over $100 \mathrm{M}$ website views per year
At $\mathrm{BMC}$, research is always in progress. 